OPEN ACCESS

ISSN 2503-3077 (Online) (online) ISSN 2503-3077 (print)

${ }^{*}$ Correspondence: Helmi Muhammad helmimuhammad@uniramalang.ac.l

Received: 10 August 2020 Accepted: 10 September 2020 Published: 10 October 2020

Citation:

Muhammad H and Sari NP (2020)

Pengaruh Financial Technology Terhadap Perbankan Syariah: Pendekatan ANP-BOCR (The Influence of Financial Technology on Islamic Banking: ANP-BOCR

Approach).

Perisai : Islamic Banking and

Finance Journal. 4:2

doi: 10.21070/perisai.v4i2.868

\section{Pengaruh Financial Technology Terhadap Perbankan Syariah: Pendekatan ANP-BOCR (The Influence of Financial Technology on Islamic Banking: ANP-BOCR Approach)}

Helmi Muhammad*, Niki Puspita Sari

Ekonomi dan Bisnis, Universitas Islam Raden Rahmat, Malang, Indonesia

The objective of this study was to examine the influence of financial technology (FinTech) on Islamic banking from the aspects of benefit, opportunity, cost and risk (BOCR). The research data were obtained through in-depth interviews and questionnaires from respondents which consisted of experts from academia, FinTech practicioners, Islamic banking practitioners and financial services authorities who were chosen by purposive sampling. The data analysis method of this research was Analytical Network Process (ANP) with the BOCR network structure approach. The results show that based on the priority aspects of the respondents' answers, rapid development of the FinTech industry provides positive opportunities for Islamic banking to implement strategic cooperation with the FinTech industry as a customer-oriented integral part.

Keywords: Financial Technology (FinTech), Islamic Banking, Analytical Network Process (ANP), BOCR

Tujuan penelitian ini adalah untuk mengkaji bagaimana pengaruh financial technology (FinTech) terhadap perbankan syariah dilihat dari aspek benefit, opportunity, cost and risk (BOCR). Data penelitian diperoleh melalui wawancara mendalam (indepth interview) dan pengisian kuisioner oleh para responden yaitu para pakar dari kalangan akademisi, praktisi dalam bidang FinTech, praktisi perbankan syariah dan praktisi dari otoritas jasa keuangan yang ditentukan secara purposive sampling. Metode analisis data penelitian ini adalah Analytical Network Process (ANP) dengan pendekatan struktur jaringan BOCR. Hasil penelitian menunjukkan bahwa berdasarkan aspek prioritas jawaban responden, perkembangan industri FinTech yang sangat cepat membuka peluang positif bagi perbankan syariah untuk melakukan kerjasama strategis dengan industri FinTech sebagai bagian integral yang berorientasi pelanggan.

Kata Kunci: Financial Technology (FinTech), Perbankan Syariah, Analytical Network Process (ANP), BOCR 


\section{PENDAHULUAN}

Inovasi teknologi telah menjadi dasar transformasi industri jasa keuangan selama 50 tahun terakhir. Saat ini, banyak teknologi baru siap untuk mendorong gelombang berikutnya dari inovasi jasa keuangan WEF (2016). Salah satu wujudnya adalah inovasi industri keuangan dalam bentuk financial technology atau FinTech (Frame et al., 2018). Industri FinTech semakin meningkat di tengah revolusi digital 4.0 di seluruh dunia dengan menawarkan inovasi jasa seperti dalam industri perbankan dan lembaga keuangan yang sudah ada (Ali et al., 2019). Industri FinTech muncul karena berbagai kendala perbankan dan lembaga keuangan tradisional, yaitu terikat dengan aturan yang sangat ketat dan keterbatasan dalam melayani masyarakat di daerah tertentu. Selain itu, berubahnya preferensi masyarakat terhadap alternatif pembiayaan yang lebih demokratis, transparan, biaya yang efisien dan menjangkau masyarakat luas (Hadad, 2017).

Data tiga tahun terakhir sejak tahun 2018 menujukkan bahwa perusahaan startup fintech dunia tumbuh lebih dari 1.700 penawaran senilai hampir \$ 40 miliar. Dalam skala global, di luar pasar inti (AS, Inggris, dan China), industri FinTech menyumbang 39\% penawaran. Pada tahun 2019, industri FinTech terus naik signifikan seiring bertambahnya area, kemajuan teknologi dan bertambahnya transaksi fintech di seluruh dunia CB-Insights (2019). Pada tahun 2020, inovator FinTech mengembangkan generasi baru bank digital pertama yang gesit, murah, dan stabil. Saat ini, ada lebih dari 75 bank penantang di seluruh dunia yang siap bersaing dengan bank tradisional (Malyshev, 2020). Bahkan menurut McKinsey seperti dinyatakan oleh Malyshev (2020), industri FinTech dunia diperkirakan mampu mendapatkan 10 hingga 40 persen dari pendapatan bank tradisional pada tahun 2025. Hal ini bisa dimaknai bahwa bank dan lembaga keuangan tradisional yang gagal bereaksi terhadap industri FinTech akan mengalami penurunan laba yang signifikan. Pada saat yang sama, lembaga keuangan yang memanfaatkan teknologi baru akan meraih peluang pertumbuhan.

Pertumbuhan industri FinTech dunia yang pesat tersebut telah mengubah lanskap bisnis industri perbankan untuk lebih inovatif. Bahkan ada kecenderungan untuk meningkatkan investasi dalam industri FinTech, memikirkan kembali saluran distribusi layanan, terutama model bisnis layanan langsung ke konsumen, meningkatkan standarisasi fungsi back office dan sebagainya. Beberapa anggota industri jasa keuangan melihat booming FinTech tersebut sebagai ancaman bagi industri perbankan tradisional. Namun di lain pihak percaya bahwa pertumbuhan industri FinTech bisa menjadi peluang karena memberikan lebih banyak fleksibilitas, fungsionalitas yang lebih baik di beberapa bidang, dan agregasi layanan (Romānova and Kudinska, 2016). Meskipun dalam beberapa hal, industri FinTech mengandung biaya investasi tinggi, namun munculnya model bisnis inovatif dengan teknologi canggih seperti Blockchain, internet of things, kecerdasan buatan (artificial intelligence) dan robotika setidaknya mempengaruhi masa depan industri perbankan dan keuangan.

Tak terkecuali di Indonesia dengan sistem keuangan yang mengalami pertumbuhan cepat di dunia (Anshari et al., 2020). Pertumbuhan startup dalam industri FinTech dalam bidang pembayaran, pengiriman uang, mata uang digital dan lainnya berkonsekuensi pada pengaturan dan pengawasan yang baik oleh pemerintah Alam et al. (2019) karena telah menciptakan ekosistem keuangan alternatif yang tersedia untuk pelanggan dan bisnis. Bahkan pertumbuhan FinTech juga menjadi pesaing industri perbankan dan keuangan tradisional yang sudah mapan dalam bentuk layanan, produk, dan jasa pengiriman. Disinyalir dalam lima tahun ke depan, sekitar US\$ 500 miliar akan diinvestasikan untuk mengembangkan infrastruktur yang diperlukan untuk FinTech di Indonesia (Anshari et al., 2020). Data pada bulan Mei 2020 tercatat bahwa perusahaan terdaftar/berizin dalam industri FinTech sebanyak 161 perusahaan. Dari jumlah tersebut, sebanyak 106 berstatus perusahaan lokal dan 55 berstatus perusahaan asing. Jumlah outstanding pinjaman dalam tiga tahun terakhir mengalami fluktuasi namun tetap mengalami peningkatan signifikan yaitu $\mathrm{Rp}$ 5,04 T tahun 2018, Rp 13, $16 \mathrm{~T}$ tahun 2019 dan Rp 12, $86 \mathrm{~T}$ pada bulan Mei 2020 yang naik 54,64\% yoy dengan akumulasi penyaluran pinjaman secara nasional Rp 109,18 T, naik $166,03 \%$ yoy (OJK, 2020).

Data otentik pertumbuhan industri FinTech di Indonesia tersebut jelas menunjukkan potensi bagi industri perbankan yang sudah mapan, baik perbankan konvensional maupun syariah yang harus direspon secara cepat dalam berbagai aspek benefit, opprtunities, cost dan risk. Hanya saja, reaksi industri perbankan syariah terhadap industri Fintech dan dampak potensialnya sangat lambat dibandingkan dengan industri perbankan konvensional (Ali et al., 2019). Reaksi yang lambat tersebut bisa dimaknai bahwa perbankan syariah belum menganggap FinTech sebagai sebuah peluang dan keuntungan untuk meningkatkan daya saing. Idealnya penerapan fintech dalam industri perbankan syariah harus disambut baik dengan tetap mematuhi prinsip-prinsip dan aturan-aturan syariah seperti larangan bunga (riba), judi (maysir), ketidakpastian (gharar), bahaya (darar), curang (tadlis) (Ali et al., 2019; Todorof, 2018), selain model bisnisnya yang memegang nilai-nilai etis Alam et al. (2019). Selain itu kecenderungan melemahnya kepercayaan pada industri perbankan konvensional, penetrasi internet dan teknologi secara global, dan keinginan masyarakat pada sistem keuangan yang dapat dipercaya yang memicu pertumbuhan industri FinTech Islam Alam et al. (2019) harus ditangkap sebagai peluang bagi perbankan syariah. Juga, pengenalan FinTech dalam perbankan syariah mestinya dapat meningkatkan daya saing dan inklusif secara umum dengan memasukkan lebih banyak produk dan layanan sehingga pemerintah bisa mengidentifikasi arah masa depan industri perbankan syariah. Namun, kondisi ideal ini masih jauh dari harapan dalam industri perbankan syariah dalam menyikapi pertumbuhan industri Fintech yang sangat cepat.

Permasalahan tersebut menarik untuk dikaji bagaimana pengaruh pertumbuhan industri FinTech terhadap perbankan 
syariah dilihat dari aspek benefit, opportunities, cost and risk (BOCR). Penelitian ini memungkinkan memperoleh hasil yang bisa dipakai para pemegang kebijakan perbankan syariah dalam mengambil keputusan dengan melakukan berbagai pertimbangan melalui pengalaman empirik dalam struktur jaringan BOCR. Kajian penelitian ini juga penting karena merekomendasikan secara strategis melalui identifikasi, klasifikasi dan menyusun faktor-faktor dalam keputusan strategis terkait perkembangan industri FinTech dan pengaruhnya terhadap perbankan syariah dalam struktur BOCR. Harapannya perbankan syariah bisa bersaing secara cepat dangan industri perbankan dan keuangan lainnya dalam ekosistem keuangan yang semakin maju dan inovatif.

\section{LITERATUR REVIEW}

\section{Definisi FinTech}

FinTech adalah istilah yang sangat populer dengan beragam definisi yang sampai saat ini belum ada kesepakatan (Schueffel, 2017; Thakor, 2020). FinTech dimaknai dalam arti sempit sebagai penggunaan teknologi untuk solusi masalah keuangan (Arner et al., 2015). Juga didefinisikan sebagai penggunaan aplikasi teknologi digital untuk mengatasi masalah-masalah intermediasi keuangan (Aaron et al., 2017). Secara luas FinTech diartikan sebagai inovasi teknologi keuangan yang menghasilkan model bisnis, aplikasi, proses, atau produk baru dengan efek material yang berkaitan dengan lembaga keuangan dan penyediaan layanan keuangan (FSB, 2017). Bahkan definisi ini juga telah diadopsi oleh Basel Committee on Banking Supervision untuk pengembangan industri FinTech BIS (2018). Juga dimaknai sebagai industri keuangan baru yang menerapkan teknologi untuk meningkatkan aktivitas keuangan (Schueffel, 2017). Definisi yang disampaikan oleh Schueffel (2017) adalah hasil review 200 jurnal ilmiah dalam kurun waktu 40 tahun sebagai tawaran definisi FinTech yang berbeda dan ringkas meskipun bukan definisi akhir. Sintesis dari banyak definisi FinTech tersebut adalah industri keuangan yang menerapkan teknologi untuk menyediakan layanan dan meningkatkan aktivitas keuangan. Kendatipun definisi FinTech ini bukanlah statis tunggal, namun dalam penelitian ini, istilah FinTech dikaitkan penggunaan teknologi yang membantu industri keuangan dan perbankan dalam melakukan pelayanan kepada masyarakat guna meningkatkan aktivitas keuangan.

\section{Tiga Fase Perkembangan FinTech}

FinTech adalah perpaduan layanan keuangan industri perbankan dan lembaga keuangan dengan teknologi yang sudah berjalan lama. Arner et al. (2015) menjelaskan tiga kurun waktu FinTech yaitu, pertama, FinTech 1.0 (1866-1967), ditandai dengan penemuan ATM dan teknologi telegraf yang memungkinkan transmisi, informasi, transaksi keuangan secara cepat. Kedua FinTech 2.0 (1967-2008), didominasi oleh industri jasa keuangan tradisional yang mengenalkan pemba- yaran elektronik, sistem kliring, mesin ATM dan layanan perbankan online. Ketiga FinTech 3.0 (2008-sekarang), perusahaan teknologi mapan mulai memberikan produk dan layanan keuangan langsung ke bisnis dan masyarakat umum dalam satu perangkat teknologi mutakhir dengan platform online. Tiga fase perkembangan FinTech tersebut terangkum dalam gambar berikut:

\section{[Figure 1 about here.]}

Sumber: Arner et al. (2015)

\section{Aktivitas-aktivitas FinTech dalam Layanan Jasa Keuangan}

Bidang-bidang yang dicakup oleh FinTech meiliputi beberapa hal (FSB, 2017; Navaretti et al., 2018), yaitu:

1. Kredit, deposito, dan layanan peningkatan modal. Dalam hal ini FinTech melayani deposito, pinjaman dan penambahan modal (captal rising) dengan inovasi yanag paling umum seperti crowdfunding dan paltform pinjaman P2P (peer-to-peer) secara online.

2. Pembayaran, kliring dan layanan penyelesaian, termasuk mata uang digital. Dalam aktivitas ini, FinTech berkaitan dengan pembayaran mobile yang dilakukan lembaga keuangan atau perbankan, dompet elektronik (digital wallet) dan penggunaan buku besar terdistribusi untuk infrastruktur pembayaran. Tujuan berbagai model ini adalah untuk meningkatkan inklusi keuangan dan memastikan akses konsumen secara baik dalam sejumlah besar transaksi, transfer dan penyelesaian antar lembaga keuangan.

3. Jasa manajemen investasi (termasuk perdagangan). FintTech juga menyediakan platform e-trading yang membantu konsumen secara mudah melakukan investasi secara langsung melalui jaringan komputer pada semua jenis aset melalui smart contracts, robo-advice berkaitan manajemen investasi dan porto folio.

4. Manajemen Risiko dan Asuransi. Layanan perusahaan FinTech dalam bidang asuransi (insur-tech), underwriting, penentapan harga risiko dan klaim.

5. Dukungan Pasar. Teknologi FinTech juga menyediakan eaggregators, big data, verifikasi ID secara digital, penyimpanan dan pemrosesan data secara claud dan smart contracts.

Keberhasilan Inovasi industri FinTech tersebut mengharuskan regulasi yang transparan dan jelas bagi startup baru, industri perbankan dan perusahaan inovasi keuangan Alam et al. (2019). Beberapa hasil penelitian menunjukkan pentingnya peran regulator (negara) dalam menyediakan platform bagi perusahaan FinTech untuk mempromosikan inovasi di bidang layanan keuangan serta menjaga kepentingan konsumen dan investor . Setidaknya ada dua faktor utama terjadinya evolusi dalam inovasi FinTech (Awrey, 2013), pertama adalah pergeseran preferensi masyarakat terutama generasi melenial 
yang tumbuh dalam lingkungan digital. Juga, kemudahan akses internet mendorong ekspektasi terhadap kenyamanan, kecepatan, biaya dan kemudahan layanan keuangan. Kedua adalah munculnya bisnis yang menggunakan teknologi seperti big data, artificial intelligence, blockchain, dan cryptocurrency yang saat ini berkembang pesat (Frame et al., 2018; Khan and Kannapiran, 2019).

Perkembangan FinTech yang sangat cepat sebenarnya bukanlah alasan bagi industri perbankan baik konvensional ataupun syariah untuk tidak terbuka terhadap inovasi keuangan FinTech. Namun beberapa kendala tetap harus diantisipasi, pertama akselerasi inovasi FinTech yang melebihi perkembangan inovasi industri perbankan. Kedua, industri perbankan tunduk pada peraturan yang sangat ketat sementara sebagian besar industri FinTech masih ada celah regulasi yang belum mengaturnya (Drummer et al., 2016). Namun optimisme tetap ada bahwa industri perbankan harus bersinergi dengan industri Fintech secara baik untuk memaksimalkan keuntungan finansial bagi perbankan (meskipun tetap mengikuti aturan perbankan). Dalam arti lain bahwa meskipun industri FinTech memberikan tantangan yang signifikan karena akselerasi inovasi teknologi bagi dunia perbankan, namun kemampuan FinTech dalam menjangkau masyarakat dan melakukannya dengan harga yang lebih rendah harus dijadikan peluang dan dimanfaatkan untuk mencapai keuntungan.

\section{METODE PENELITIAN}

Penelitian ini menggunakan pendekatan kualitattif dari data yang diperoleh melalui wawancara mendalam (indepth interview) dan pengisian kuisioner oleh para responden. Responden dalam penelitian ini adalah para pakar dari kalangan akademisi, praktisi dalam bidang FinTech, praktisi perbankan syariah dan praktisi dari otoritas jasa keuangan yang ditentukan secara purposive sampling. Metode analisis data penelitian ini adalah Analytical Network Process (ANP) dengan pendekatan struktur jaringan Benefit, Opportunity, Cost and Risk (BOCR) untuk mengidentifikasi, mengklasifikasi dan mengatur semua faktor dan kepentingan yang mempengaruhi hasil keputusan (Saaty and Vargas, 2013). Selain itu, analisis ANP memungkinkan umpan balik dan saling ketergantungan diantara kriteria dalam struktur jaringan BOCR sehingga memudahkan pengambilan keputusan (Saaty and Vargas, 2013)

\section{HASIL PENELITIAN DAN PEMBAHASAN}

Secara umum hasil wawancara dan pengisian kuisioner oleh para responden terkait dengan pengaruh FinTech bagi perbankan syariah dibagi menjadi dua aspek yaitu positif dan negatif. Aspek positif dikelompokkan dalam sub jaringan benefit dan opportunity, sedangkan aspek negatif masuk dalam sub jaringan cost dan risk. Pendekatan benefit, opportunity, cost dan risk (BOCR) tersebut merupakan analisis kondisi sekarang (jangka pendek) dan masa yang akan datang (jangka panjang) yang mungkin terjadi (Shang et al., 2004). Untuk mendapatkan prioritas dari setiap elemen BOCR dilakukan dengan menghitung nilai rata-rata normalized by cluster masingmasing responden. Adapaun hasil wawancara dan pengisian kuisioner oleh para responden dalam struktur jaringan BOCR terangkum dalam tabel berikut:

[Table 1 about here.]

\section{Aspek Benefit}

Aspek benefit merupakan aspek yang memberikan manfaat atau keunggulan bagi perbankan syariah dengan adanya FinTech. Tabel tersebut menunjukkan paparan data masingmasing klaster dalam struktur BOCR. Dalam analisis aspek benefit diketahui bahwa faktor yang paling prioritas adalah hemat biaya operasional dan pemasaran melalui kolaborasi dengan FinTech sebanyak 28\%, diikuti FinTech menjadi basis data bagi perbankan syariah sebesar $22 \%$, meningkatkan value perbankan syariah, $21 \%$, memperluas market share perbankan syariah, $17 \%$ dan mempermudah pengawasan oleh otoritas sebesar $12 \%$. Dalam persepsi responden kolaborasi perbankan syariah dengan FinTech sangat strategis sebagai bagian integral. Saat individualisasi layanan keuangan meningkat karena pengaruh digital, akan memangkas biaya operasional perbankan syariah. Selain itu kerjasama yang baik dengan FinTech, memungkinkan perbankan syariah memasarkan produk/layanan seperti pembayaran, produk tabungan, giro, kredit dan sebagainya sehingga jangkauan pasarnya semakin luas. Hasil penelitian yang dilakukan oleh Romānova and Kudinska (2016) menjelaskan hal yang sama. Perusahaan FinTech juga menyediakan layanan gratis untuk layanan bank memungkinkan dilakukan kemitraan. Perbankan syariah bisa menggunakan keunggulan komparatif perusahaan FinTech sebagai layanan keuangan berstandar tinggi dan berbiaya rendah dengan risiko layanan/produk keuangan yang relatif lebih rendah (misalnya, risiko gagal bayar, risiko jatuh tempo) karena cakupan teknologi yang berorientasi pada perilaku konsumen.

\section{Aspek Opportunity}

Aspek opportunity adalah peluang yang menguntungkan bagi perbankan syariah karena pengaruh FinTech. Analisis aspek opportunity menunjukkan bahwa aspek yang paling prioritas adalah sarana marketing perbankan syariah sebesar $22 \%$, kemudian kolaborasi antara start up FinTech dengan perbankan syariah, $21 \%$, meningkatkan potensi penyaluran kredit sektor mikro terutama masyarakat unbanked sebesar $20 \%$ dan terakhir pembiayaan perbankan syariah dapata dilink dengan FinTech, 18\%. Sebagian besar responden memiliki persepsi 
bahwa industri FinTech merupakan peluang mempromosikan perbankan syariah sebagai lembaga keuangan inklusif yang menyediakan layanan keuangan terutama kepada masyarakat yang belum mengenal bahkan belum memiliki rekening bank. Masyarakat milenial yang sudah terbiasa dengan layanan digital melalui teknologi seluler akan dengan mudah mengenal dan mempromosikan industri perbankan syariah. Menurut survey Mobile Payments \& Fraud: 2018 Report menyatakan bahwa strategi seluler memegang peranan sangat penting dalam mendukung industri keuangan inklusif, peranan, produk dan layanan yang sejalan dengan industri FinTech (Kaount, 2018). Hasil penelitian ini juga menguatkan argumentasi penelitian Ali et al. (2019) yang menyatakan bahwa FinTech memiliki potensi positif yang mendorong perbankan syariah memanfaatkan peluang yang ditawarkan oleh pergeseran digital dan Fintech seperti memperkenalkan model bisnis baru, lebih transparan, efisiensi dalam produk dan menyediakan layanan keuangan Islam yang ramah pelanggan.

\section{Aspek Cost}

Aspek cost adalah aspek biaya karena FinTech yang dirterapkan bagi perkembangan perbankan syariah. Analisis cost menunjukkan bahwa biaya penyiapan logistik, infrastruktur pendukung FinTech dan biaya sistem keamanan adalah menjadi prioritas yaitu sebesar $25 \%$, diikuti biaya pengurangan SDM karena perbankan syariah berbasis FinTech dengan nilai $22 \%$, biaya promosi dengan nilai $15 \%$ dan alokasi SDM khusus untuk operasional FinTech sebesar 12\%. Secara umum, responden menyatakan bahwa infrastruktur pendukung FinTech mengandung biaya tinggi. Teknologi seperti artificial intelligence, big data, internet of thing's (IoT's) dan sistem robotik termasuk salah satu instrumen pendukung Fintech, sehingga eksistensinya diperlukan persiapan yang matang. Hasil penelitian sebelumnya seperti dilakukan oleh Ali et al. (2019) mengisyaratkan pentingnya infrastruktur pendukung FinTech seperti teknologi digital dan komputasi awan (cloud computing) dalam industri keuangan Islam meskipun juga menyisakan risiko besar seperti keamanan data, serangan cyber (cyber attacks) dan risiko hukum (legal risk). Survei sebelumnya juga menunjukkan bahwa reaksi bank terhadap perkembangan FinTech di dunia berbeda-beda, namun secara umum industri perbankan harus menyiapkan dana ventura untuk membiayai FinTech dalam jumlah besar (Romānova and Kudinska, 2016), dan ini menjadi tantangan bagi perbankan syariah di Indonesia yang masih memiliki banyak keterbatasan.

\section{Aspek Risk}

Aspek risk adalah berbagai risiko yang harus ditanggung perbankan syariah karena adanya FinTech. Hasil analisis aspek risk berdasarkan pengolahan data menunjukkan bahwa prioritas aspek risiko adalah beberapa pasar akan diambil oleh FinTech dengan nilai $24 \%$, diikuti dengan risiko penipuan bagi nasabah yang menggunakan FinTech sebesar 23\%, kemudian risiko interoperabilitas 20\%, banyak FinTech yang gagal atau tidak berpengaruh terhadap kenaikan dana pihak ketiga sebesar 18\% dan terakhir adalah keterbatasan SDM yang memahami FinTech 16\%. Secara umum responden menyatakan bahwa aspek pangsa pasar menjadi risiiko serius bagi perbankan syariah, meskipun tidak menafikan risiko penting lainnya. Tergerusnya pangsa pasar perbankan syariah oleh industri FinTech akan menjadi ancaman serius apabila perbankan syariah mengabaikan strategi yang tepat. Pernyataan responden ini sejalan dengan keterangan Malyshev (2020) yang menjelaskan laporan McKinsey bahwa industri FinTech akan menggerus pendapatan bank tradisional pada tahun 2025 sebesar 10\% hingga 40\%. Apabila industri FinTech tumbuh secara cepat maka perbankan syariah juga harus mengimbanginya dengan respon yang cepat pula. Kolaborasi bisa menjadi salah satu strategi yang tepat guna menekan dampak tersebut. Secara umum, industri perbankan lebih fokus pada produk, sementara industri FinTech cenderung fokus pada pelanggan (Vives, 2017). Kondisi ini menjadi celah industri FinTech menekan model bisnis industri perbankan. Kekhawatiran berbagai risiko ini telah menjadi isu dunia dalam laporan Jenewa ke 22 tentang ekonomi dunia yang fokus pada tantangan industri FinTech terhadap industri perbankan global yang merekomendasikan masa depan industri keuangan yang positif (Petralia et al., 2019).

\section{Analisis BOCR}

Analisis BOCR digunakan untuk menganalisis empat aspek yang menjadi prioritas berdasarkan nilai rata-rata gabungan. Hasil prioritas secara keseluruhan berdasarkan empat aspek tersebut menjadi perhatian dalam pengambilan keputusan ke depan berdasarkan pendapat gabungan para responden. Nilai aspek BOCR yang dinormalkan (normalized by cluster) adalah dasar penentuan prioritas. Aspek BOCR yang memiliki nilai yang lebih besar memiliki tingkat yang lebih tinggi begitu juga sebaliknya. Berdasarkan hasil pengolahan data, diketahui bahwa aspek opportunity memiliki nilai tertinggi sebesar 43\%, diikuti aspek benefit sebesar $28 \%$, kemudian aspek cost sebesar $15 \%$ dan aspek risk sebesar 14\%. Urutan prioritas aspek BOCR seperti pada tabel berikut:

[Table 2 about here.]

Hasil pengolahan ANP berdasarkan aspek BOCR juga nampak dari hasil rater agreement yaitu kesepakatan responden dalam memilih prioritas aspek BOCR seperti pada gambar berikut:

\section{[Figure 2 about here.]}

Hasil tersebut mengindikasikan bahwa para pakar yang menjadi responden sebagian besar sepakat bahwa prioritas dari aspek BOCR adalah opportunity diikuti aspek benefit, cost dan risk. Artinya para pakar memandang bahwa keberadaan 
FinTech bagi perkembangan perbankan syariah di Indonesia adalah peluang yang memberikan harapan. Peluang tersebut bisa diraih dengan melakukan sinergi atau kerjasama perbankan syariah dengan industri FinTech. Banyak produk perbankan syariah berbasis teknologi informasi yang dapat dibeli dari berbagai penyedia layanan keuangan. Juga, metode analisis data modern dan teknologi informasi saat ini memungkinkan individualisasi banyak layanan keuangan secara digital yang berorientasi kepada pelanggan (Dapp, 2014). Dan ini adalah tantangan bagi perbankan syariah juga industri keuangan lainnya. Maka sangat penting bagi perbankan syariah menjalin kerja sama dengan FinTech dalam bentuk kemitraan strategis (in-door solutions). Riset-riset terdahulu secara umum juga mengisyaratkan perlunya kerjasama industri keuangan dengan industri Fintech sebagai arah strategis yang prospektif di masa depan .

Kerjasama strategis dengan penyedia FinTech akan memungkinkan perbankan syariah menggunakan keunggulan komparatif industri FinTech. Romānova and Kudinska (2016) menjelaskan beberapa keunggulan FinTech antara lain adalah layanan keuangan yang terstandar dan berbiaya rendah, berbasis internet, tidak terkonsentrasi secara geografis karena menjangkau semua wilayah, mampu merubah perilaku konsumen, regulasi layanan keuangan yang masih longgar. Namun demikian perbankan syariah juga memiliki keunggulan komparatif antara lain yaitu pengalaman layanan keuangan yang panjang dengan keahlian yang matang seperti penyediaan produk keuangan yang kompleks, pinjaman korporasi, manajemen risiko, intermediasi keuangan dan lainnya. Semua produk keuangan yang komplek tersebut memerlukan skill dengan kualifikasi yang tinggi. Selain itu, regulasi yang sangat ketat memiliki tujuan untuk membentuk lingkungan bisnis perbankan syariah yang didasarkan pada keamanan data, dan ini adalah prasyarat penting penggunaan teknologi keuangan. Bahkan hasil penelitian sebelumnya juga menegaskan bahwa industri perbankan akan melakukan tranfsormasi sebagai akibat krisis keuangan, perubahan perilaku nasabah perbankan, inovasi teknologi informasi dan layanan keuangan non-bank (Alt and Puschmann, 2012). Beberapa faktor tersebut mengharuskan industri perbankan melakukan reposisi yang berorientasi pada pelanggan.

Hadad (2017) menjelaskan bahwa keberadaan industri FinTech di Indonesia perlu dioptimalkan peran dan fungsinya dengan membangun sinergi bisnis antara industri FinTech dan industri perbankan dengan berapa bentuk, pertama, data nasabah dan jalur distribusi (distribution channel) yang telah dibangun lama oleh lembagan keuangan perlu dikolaborasikan dengan industri FinTech. Kedua, untuk meningkatkan efisiensi bisnis industri perbankan diperlukan pemanfaatan fungsi FinTech. Ketiga, kolaborasi melalui proses desain (desain thinking) produk dan bundling product antara produk FinTech dan industri perbankan yang menjadi solusi bagi konsumen dan bermanfaat bagi kedua pihak. Keempat, kesamaan sektor bisnis, artinya sinergi dilakukan hanya oleh perbankan yang memiliki bisnis inti di sektor UMKM dan FinTech yang menyediakan platform UMKM digital. Apa yang disampaikan oleh Hadad (2017) menunjukkan bahwa ada peluang besar pola kerjasama industri perbankan syariah dengan industri Fintech dengan seperangkat regulasi yang mengaturnya. Meskipun reaksi industri perbankan syariah terhadap perkembangan FinTech terkesan lambat daripada perbankan konvensional (Ali et al., 2019), namun masih terbuka peluang untuk melakukan perubahan melalui kerjasama strategis dengan industri FinTech sebagai bagian integral.

Kerjasama strategis melaui sinergi FinTech dan perbankan Syariah memiliki dampak positif bagi perbankan. Hasil penelitian yang dilakukan oleh Todorof (2018) menjadi dasar penguat argumentasi para responden dalam penelitian ini. Teknologi FinTech yang selama ini dipakai oleh perbankan konvensional juga memicu penyelarasan dalam perbankan syariah, terutama regulasi syariah yang memberikan rasa aman nasabah dan menjamin produk tersebut halal. Sinergi ini akan meningkatkan daya saing perbankan syariah dalam bentuk transparansi transaksi keuangan yang bisa diamati oleh para pelaku perbankan syariah, otoritas yang berwenang dan nasabah. Peran Dewan Syariah Nasonal Majelis Ulama Indonesia memiliki peran sentral dalam merumuskan aturan syariah yang menjamin penerapan Fintech dalam perbankan syariah adalah halal. Seperangkat hukum akad harus disiapkan kaitannya dengan aktifitas-aktivitas FinTech yang diterapkan di perbankan syariah yang menjadi operasional teknis. Dengan demikian, perbankan syariah memiliki peluang besar dalam memanfaatkan FinTech untuk meningkatkan efisiensi dan inklusi keuangan dengan tetap berpegang pada aturan syariah yang ditetapkan.

\section{KESIMPULAN}

Perkembangan industri FinTech yang semakin meningkat menawarkan berbagai inovasi layanan keuangan seperti dalam industri perbankan dan lembaga keuangan yang sudah ada. Peran dan fungsi industri FinTech semakin penting dalam sektor keuangan karena nilai tambah yang diberikan terutama inovasi teknologi informasi sehingga perbankan syariah harus merespon dengan baik dari beberapa aspek. Dari aspek benefit diketahui bahwa faktor prioritas adalah hemat biaya operasional dan pemasaran melalui kolaborasi dengan FinTech. Aspek opportunity antara lain bahwa FinTech merupakan peluang mempromosikan perbankan syariah sebagai lembaga keuangan inklusif yang menyediakan layanan keuangan kepada masyarakat. Faktor prioritas dari aspek cost adalah infrastruktur pendukung FinTech mengandung biaya tinggi sehingga diperlukan persiapan yang matang. Aspek pangsa pasar menjadi faktor risk serius bagi perbankan syariah. Tergerusnya pangsa pasar perbankan syariah oleh industri FinTech menjadi ancaman serius apabila perbankan syariah mengabaikan strategi yang tepat. Namun, secara umum keberadaan FinTech bagi perkembangan perbankan syariah di Indonesia adalah peluang (opportunity) yang memberikan 
harapan. Peluang tersebut bisa diraih dengan melakukan sinergi atau kerjasama strategis perbankan syariah dengan indus-

\section{REFERENCES}

Aaron, M., Rivadeneyra, F., Sohal, S., and Bank of Canada Staff Discussion Paper (2017). Fintech: Is this time different? A framework for assessing risks and opportunities for central banks (Working Paper No. 2017-10). Bank of Canada Staff Discussion Paper website. https://www.econstor.eu/handle/10419/200480.

Alam, N., Gupta, L., and Zameni, A. (2019). Challenges and Success Factors for Islamic Fintech (Cham: Springer International Publishing), 159-173.

Ali, H., Abdullah, R., and Zaini, M. Z. (2019). Fintech and Its Potential Impact on Islamic Banking and Finance Industry: A Case Study of Brunei Darussalam and Malaysia. International Journal of Islamic Economics and Finance (IJIEF) 2. doi: 10.18196/ijief.2116.

Alt, R. and Puschmann, T. (2012). The rise of customer-oriented banking - electronic markets are paving the way for change in the financial industry. Electronic Markets 22, 203-215. doi: 10.1007/s12525-012-0106-2.

Anshari, M., Almunawar, M. N., and Masri, M. (2020). An Overview of Financial Technology in Indonesia.

Arner, D. W., Barberis, J. N., and Buckley, R. P. (2015). The Evolution of Fintech: A New Post-Crisis Paradigm? SSRN Electronic Journal. doi: 10.2139/ssrn.2676553.

Awrey, D. (2013). Toward a supply-side theory of financial innovation. Journal of Comparative Economics 41, 401-419. doi: 10.1016/j.jce.2013.03.011.

BIS (2018). Sound Practices: Implications of fintech developments for banks and bank supervisors. Bank for International Sattlements. https://www.bis.org/bcbs/ publ/d431.htm.

CB-Insights (2019). Fintech Trends \& Industry Overview | CB Insights. https: //www.cbinsights.com/research/report/fintech-trends-2019/.

Dapp, T. F. (2014). Fintech - The digital (r)evolution in the financial sector Algorithm-based banking with the human touch. . https://www.finextra.com/ finextra-downloads/featuredocs/prod0000000000345837.pdf.

Drummer, D., Jerenz, A., Siebelt, P., and Thaten, M. (2016). FinTech - Challenges and Opportunities. http://cryptochainuni.com/wp-content/uploads/ McKinsey-Company-FinTech-Challenges-and-Opportunities.pdf.

Frame, W., Wall, L., and White, L. (2018). Technological Change and Financial Innovation in Banking: Some Implications for Fintech. Federal Reserve Bank of Atlanta, Working Papers.

FSB (2017). Financial Stability Implications from FinTech. Financial Stability Board. https://www.fsb.org/2017/06/financial-stability-implications-from-fintech/.

Hadad, M. D. (2017). Financial Technology (FinTech) di Indonesia. http://www. ibs.ac.id/img/doc/MDH\%20-\%20FinTech\%20IBS\%20June\%202017.pdf.

Kaount (2018). Mobile Payments \& Fraud. https://www.jhacanada.com/WhitePaper-Mobile-Payments-and-Fraud-2018-Report.pdf.

Khan, S. and Kannapiran, T. (2019). Indexing Issues in Spatial Big Data Management. SSRN Electronic Journal. doi: 10.2139/ssrn.3387792. tri FinTech sebagai bagian integral yang tidak dapat dipisahkan.
Malyshev, A. (2020). Core Banking Software Solution \& Wallet Engine | SDK. https://sdk.finance/top-fintech-trends-2020/.

Navaretti, G. B., Calzolari, G., Mansilla-Fernandez, J. M., and Pozzolo, A. F. (2018). Fintech and Banking. Friends or Foes? SSRN Electronic Journal. doi: 10.2139/ ssrn.3099337.

OJK (2020). Statistik Fintech Lending Periode Mei 2020. Otoritas Jasa Keuangan. https://www.ojk.go.id/id/kanal/iknb/data-dan-statistik/fintech/Pages/ -Statistik-Fintech-Lending-Periode-Mei-2020.aspx.

Petralia, K., Philippon, T., Rice, T., and Veron, N. (2019). The disruptive impact of new technology on the banking industry. https://www.weforum.org/agenda/ 2019/09/disruptive-impact-new-technology-banking-industry/.

Romānova, I. and Kudinska, M. (2016). Banking and Fintech: A Challenge or Opportunity? Contemporary Studies in Economic and Financial Analysis 98, 2135.

Saaty, T. L. and Vargas, L. G. (2013). Decision Making with the Analytic Network Process (Boston, MA: Springer US).

Schueffel, P. (2017). Taming the Beast: A Scientific Definition of Fintech. Journal of Innovation Management 4, 32-54. doi: 10.24840/2183-0606_004.004_0004.

Shang, J. S., Tjader, Y., and Ding, Y. (2004). A Unified Framework for Multicriteria Evaluation of Transportation Projects. IEEE Transactions on Engineering Management 51, 300-313. doi: 10.1109/tem.2004.830848.

Thakor, A. V. (2020). Fintech and banking: What do we know? Journal of Financial Intermediation 41, 100833-100833. doi: 10.1016/j.jfi.2019.100833.

Todorof, M. (2018). Shariah-compliant FinTech in the banking industry. ERA Forum 19, 1-17. doi: 10.1007/s12027-018-0505-8.

Vives, X. (2017). The Impact of Fintech on Banking.

WEF (2016). The future of financial infrastructure An ambitious look at how blockchain can reshape financial services. World Economic Forum. http: //www3.weforum.org/docs/WEF_The_future_of_financial_infrastructure.pdf.

Conflict of Interest Statement: The authors declare that the research was conducted in the absence of any commercial or financial relationships that could be construed as a potential conflict of interest.

Copyright (c) 2020 Muhammad and Sari. This is an open-access article distributed under the terms of the Creative Commons Attribution License (CC BY). The use, distribution or reproduction in other forums is permitted, provided the original author(s) and the copyright owner(s) are credited and that the original publication in this journal is cited, in accordance with accepted academic practice. No use, distribution or reproduction is permitted which does not comply with these terms. 


\section{LIST OF TABLES}

1 Paparan Data Wawancara dan Pengisian Kuisioner . . . . . . . . . . . . . . . . . . . . . . . 121

2 Urutan Prioritas Aspek BOCR . . . . . . . . . . . . . . . . . . . . . . . . . 122 
TABLE 1 | Paparan Data Wawancara dan Pengisian Kuisioner

\begin{tabular}{|c|c|c|c|c|c|c|}
\hline \multirow[b]{2}{*}{ Aspek } & \multirow{2}{*}{ Kriteria } & \multicolumn{5}{|c|}{ Normalized by cluster } \\
\hline & & $\mathrm{R} 1$ & $\mathrm{R} 2$ & R3 & $\mathrm{R} 4$ & R5 \\
\hline $\begin{array}{l}\text { Ben- } \\
\text { efit }\end{array}$ & $\begin{array}{l}\text { - Memperluas market share perbankan syariah } \bullet \text { Meningkatkan value bank } \\
\text { syariah (dari aset dan IT) } \bullet \text { Menjadi basis data perbankan syariah } \bullet \text { Hemat biaya } \\
\text { operasional dan pemasaran melalui kolaborasi dengan FinTech } \bullet \text { Mempermudah } \\
\text { pengawasan pembiayaan perbankan syariah oleh otoritas }\end{array}$ & $\begin{array}{l}0.129 \\
0.084 \\
0.268 \\
0.414 \\
0.105\end{array}$ & $\begin{array}{l}0.20 .20 .2 \\
0.20 .2\end{array}$ & $\begin{array}{l}0.129 \\
0.084 \\
0.268 \\
0.414 \\
0.105\end{array}$ & $\begin{array}{l}0.184 \\
0.349 \\
0.184 \\
0.184 \\
0.098\end{array}$ & $\begin{array}{l}0.184 \\
0.349 \\
0.184 \\
0.184 \\
0.098\end{array}$ \\
\hline $\begin{array}{l}\text { Oppor- } \\
\text { tu- } \\
\text { nity }\end{array}$ & $\begin{array}{l}\text { - Era branchless banking melalui industri FinTech • Sarana marketing perbankan } \\
\text { syariah • Kolaborasi startup FinTech dengan perbankan syariah (termasuk } \\
\text { inkubasi) • Penyaluran kredit sektor mikro terutama masyarakat unbanked bisa } \\
\text { ditingkatkan • Pembiayaan dan simpanan perbankan syariah bisa diaskes } \\
\text { dengan FinTech }\end{array}$ & $\begin{array}{l}0.099 \\
0.313 \\
0.176 \\
0.313 \\
0.099\end{array}$ & $\begin{array}{l}0.20 .20 .2 \\
0.20 .2\end{array}$ & $\begin{array}{l}0.099 \\
0.313 \\
0.176 \\
0.313 \\
0.099\end{array}$ & $\begin{array}{l}0.260 \\
0.134 \\
0.260 \\
0.082 \\
0.260\end{array}$ & $\begin{array}{l}0.260 \\
0.138 \\
0.260 \\
0.082 \\
0.260\end{array}$ \\
\hline Cost & $\begin{array}{l}\text { - Alokasi SDM untuk operasional FinTech cukup mahal } \bullet \text { Biaya sistem } \\
\text { keamanan (IT security) meningkat • Biaya promosi untuk memperkenalkan } \\
\text { produk FinTech } \bullet \text { Biaya pengurangan SDM karena perbankan syariah berbasis } \\
\text { FinTech • Biaya penyiapan logistik, infrastruktur pendukung FinTech }\end{array}$ & $\begin{array}{l}0.164 \\
0.303 \\
0.164 \\
0.065 \\
0.303\end{array}$ & $\begin{array}{l}0.107 \\
0.281 \\
0.051 \\
0.281 \\
0.281\end{array}$ & $\begin{array}{l}0.164 \\
0.303 \\
0.164 \\
0.065 \\
0.303\end{array}$ & $\begin{array}{l}0.070 \\
0.192 \\
0.192 \\
0.355 \\
0.192\end{array}$ & $\begin{array}{l}0.070 \\
0.192 \\
0.192 \\
0.355 \\
0.192\end{array}$ \\
\hline Risk & $\begin{array}{l}\text { - Terbatasnya SDM perbankan syariah yang memahami FinTech • Risiko } \\
\text { penipuan nasabah pengguna FinTech • Banyak industri FinTech yang gagal dan } \\
\text { tidak berpengaruh pada kenaikan dana pihak ketiga dan pendapatan perbankan } \\
\text { - Risiko interoperabilitas (koneksi antar layanan perbankan/sistem keuangan) • } \\
\text { Beberapa pasar akan diambil oleh industri FinTech terkait dengan produk } \\
\text { perbankn syariah }\end{array}$ & $\begin{array}{l}0.215 \\
0.121 \\
0.074 \\
0.215 \\
0.376\end{array}$ & $\begin{array}{l}0.091 \\
0.091 \\
0.272 \\
0.272 \\
0.272\end{array}$ & $\begin{array}{l}0.215 \\
0.121 \\
0.074 \\
0.215 \\
0.376\end{array}$ & $\begin{array}{l}0.137 \\
0.403 \\
0.244 \\
0.137 \\
0.079\end{array}$ & $\begin{array}{l}0.137 \\
0.403 \\
0.244 \\
0.137 \\
0.079\end{array}$ \\
\hline
\end{tabular}


TABLE 2 | Urutan Prioritas Aspek BOCR

No

1

2

4
Normalized by cluster

0.277228

0.431736

0.154916

0.136120
Ranking

2

1

3
Aspek
Benefit
Opportunity
Cost
Risk

Aspek
Benefit
Opportunity
Cost
Risk 


\section{LIST OF FIGURES}

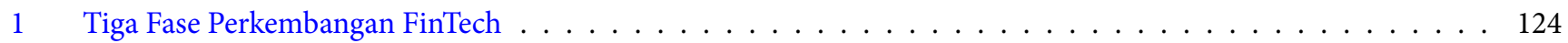

2 Grafik Prioritas Aspek BOCR 


\begin{tabular}{|c|c|c|}
\hline $\begin{array}{c}\text { FinTech } \\
\text { 1866-1967 }\end{array}$ & $\begin{array}{c}\text { FinTech } \\
\text { 1866-1967 }\end{array}$ & $\begin{array}{c}\text { FinTech } \\
\text { 1866-1967 }\end{array}$ \\
\hline $\begin{array}{l}\text { - Penggunaan } \\
\text { kabel Trans- } \\
\text { Atlantik dan } \\
\text { penemuan ATM } \\
\text { - Penggunaan } \\
\text { Telegraph }\end{array}$ & $\begin{array}{l}\text { - Pembayaran } \\
\text { elektronik, sistem } \\
\text { kliring } \\
\text { - Penggunaan mesin } \\
\text { ATM dan layanan } \\
\text { on line }\end{array}$ & $\begin{array}{l}\text { - Penggunaan } \\
\text { layanan keuangan } \\
\text { langsung ke bisnis } \\
\text { dan masyarakat } \\
\text { umum dengan } \\
\text { teknologi mutakhir }\end{array}$ \\
\hline $\begin{array}{l}\text { Transmisi cepat } \\
\text { informasi transaksi } \\
\text { keuangan dan } \\
\text { pembayaran }\end{array}$ & $\begin{array}{l}\text { Penggunaan } \\
\text { teknologi informasi } \\
\text { oleh lembaga } \\
\text { keuangan tradisional } \\
\text { untuk meningkatkan } \\
\text { produk dan layanan }\end{array}$ & $\begin{array}{l}\text { Lanskap daya saing } \\
\text { baru untuk lembaga } \\
\text { keuangan }\end{array}$ \\
\hline
\end{tabular}

FIGURE 1 | Tiga Fase Perkembangan FinTech 


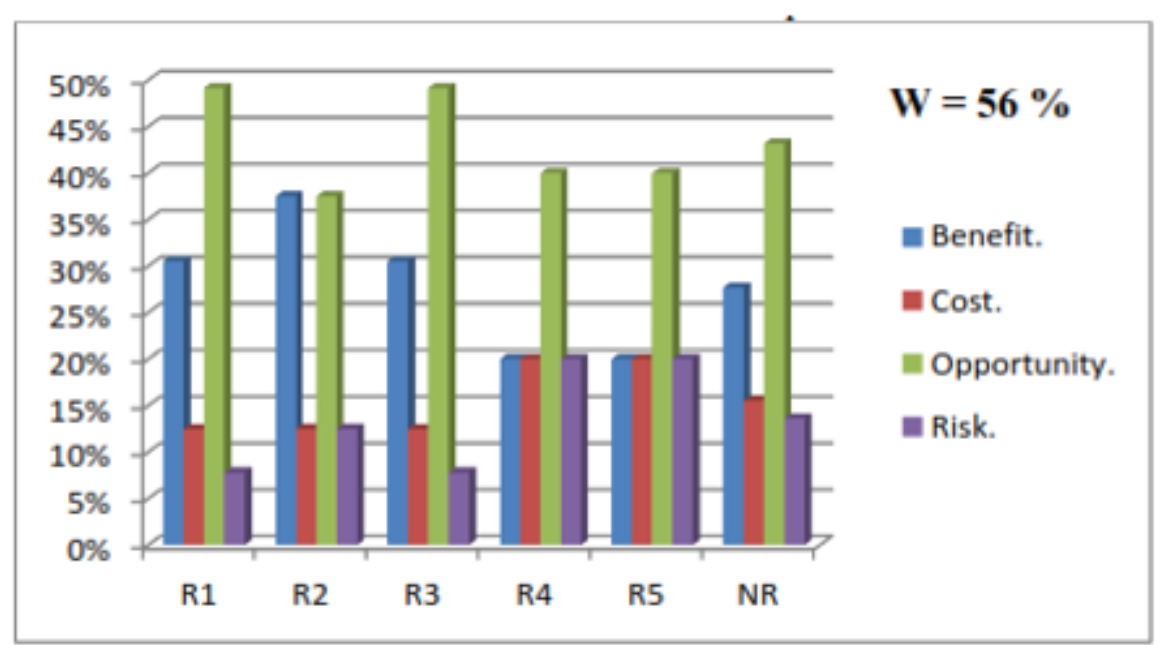

FIGURE 2 | Grafik Prioritas Aspek BOCR 